\title{
American Studies in Poland
}

\section{(2) OpenEdition}

\section{Journals}

Édition électronique

URL : https://journals.openedition.org/ejas/424

DOI : $10.4000 /$ ejas.424

ISSN : 1991-9336

Éditeur

European Association for American Studies

\section{Référence électronique}

Marek Wilczynski, «American Studies in Poland », European journal of American studies [En ligne], 1-1 । 2006, document 14, mis en ligne le 12 janvier 2006, consulté le 10 juillet 2021. URL : http:// journals.openedition.org/ejas/424; DOI : https://doi.org/10.4000/ejas.424

Ce document a été généré automatiquement le 10 juillet 2021.

Creative Commons License 


\section{American Studies in Poland}

\section{Institutions}

1 At present, American Studies is not recognized by the state educational system as a field of study in its own right, but it belongs to Modern Languages (English) listed among academic disciplines taught at Polish universities. The Polish Association for American Studies has been getting ready to take steps towards establishing American Studies as a separate discipline through proper official channels. PAAS (www.paas.org.pl) was founded in 1990 in Warsaw and now has 150 members-faculty and Ph.D. students, mostly from the university Departments of English, since American literature and culture are obligatory components of three-year B.A. programs and optional components of two-year M.A. programs in English. Moreover, American Studies is taught at the American Studies Center of the University of Warsaw (chair: Dr. Tomasz Basiuk), the Department of American Studies and Mass Media of the University of Lodz (chair: Prof. Elzbieta H. Oleksy), and the Department of American Studies of Jagiellonian University in Cracow (chair: Prof. Andrzej Mania). The School of English of Maria Curie-Sklodowska University in Lublin is the only Polish academic institution with a full program in American Studies as a major (program director: Prof. Jerzy Durczak).

2 Two American Studies journals are now published in Poland: the Polish Journal of American Studies (PAAS) and American Studies (American Studies Center, Warsaw). Both are peer-reviewed and open to submissions from all over the world. Every year the Polish Association for American Studies organizes a thematically focused international conference, usually held in the last week of October.

II. Specific fields of research

3 As most Polish scholars and students of American Studies are affiliated to the Departments of American Literature in university Schools (Institutes) of English, and there either hold or aim at earning degrees in American literature, the discipline still has a predominantly literary character determined by the European tradition of modern philology. Thus far, a Department of American Studies (part of the School of English) has been established only at Maria Curie-Sklodowska University in Lublin (chair: Prof. Jerzy Kutnik). Cultural Studies, including American Studies as well), have been also conducted and taught at the University of Silesia in Sosnowiec. 
The most popular field of research in Polish American Studies definitely has been twentieth-century American literature and culture. Among established, tenured scholars, most have been specializing in twentieth-century literature: Prof. Krzysztof Andrzejczak (Univ. of Lodz) in African-American literature, Prof. Andrzej Ceynowa (Univ. of Gdansk) in contemporary African-American drama, Prof. Jerzy Durczak (Maria Curie-Sklodowska Univ. of Lublin) in contemporary ethnic fiction and autobiography, Prof. Joanna Durczak (Maria Curie-Sklodowska Univ. of Lublin) in contemporary poetry and nature writing, Prof. Piotr Dziedzic (Univ.of Silesia) in contemporary fiction), Prof. Jadwiga Maszewska (Univ. of Lodz) in Native American fiction and literature of the American South, Prof. Agata Preis-Smith (University of Warsaw) in contemporary American poetry, and Prof. Zygmunt Mazur (Jagiellonian University, Cracow) in contemporary American fiction. A few scholars, such as Prof. Andrzej Kopcewicz (Adam Mickiewicz University of Poznan, emeritus), Prof. Zbigniew Maszewski (Univ. of Lodz), Prof. Agnieszka Salska (Univ. of Lodz) and Prof. Marek Wilczynski (Adam Mickiewicz Univ. of Poznan) have published both on nineteenth- and twentieth-century American literature. Recently, the most noteworthy joint effort of Polish Americanists has been a two-volume, comprehensive History of Twentieth-Century American Literature in Polish (ed. Agnieszka Salska, Cracow: Universitas, 2003).

5 Among the junior faculty and graduate students popular fields of interest include Chicano literature (Dr. Grazyna Zygadlo, Lodz), Afro-American literature (Dr. Ewa Luczak, Warsaw), Native American literature (Dr. Piotr Zazula, Wroclaw), gay fiction and autobiography (Dr. Tomasz Basiuk, Warsaw; Dr. Marta Mazurek, Poznan; Dr. Tomasz Sikora, Sosnowiec), women's literature and gender studies (Dr. Agnieszka Graff, Warsaw; Dr. Dominika Ferens, Wroclaw; Dr. Krystyna Mazur, Warsaw; Dr. Beata Williamson, Gdansk), science-fiction and cyberpunk (Dr. Pawel Frelik, Lublin) and contemporary poetry and fiction (Dr. Paulina Ambrozy, Poznan; Dr. Andrzej Antoszek, Lublin; Dr. Kacper Bartczak, Lodz; Dr. Jacek Gutorow, Opole; Dr. Zofia Kolbuszewska, Lublin; Dr. Grzegorz Kosc, Lodz).

6 Nineteenth-century American literature is now less often chosen as the main field of research, and only several scholars have been publishing extensively on this topic (Dr. Marek Paryz, Warsaw; Prof. Agnieszka Salska, Lodz; Prof. Marek Wilczynski, Poznan; Dr. Anna Wawrzyniak, Poznan; Dr. Magdalena Zapedowska, Poznan). Prof. Tadeusz Slawek (Univ. of Silesia, Sosnowiec) has been the most outstanding Polish scholar as regards comparative literature bordering on American Studies.

7 Non-literary American Studies in Poland range from American history (Dr. Zbigniew Mazur, Maria Curie-Sklodowska Univ. of Lublin; Prof. Krzysztof Michalek, Univ. of Warsaw; Prof. Irmina Wawrzyczek, Maria Curie-Sklodowska Univ. of Lublin) to political science (Prof. Stanislaw Filipowcz, Univ. of Warsaw; Dr. Bohdan Szklarski, Univ. of Warsaw), popular culture studies (Dr. Ewa Grzeszczyk, Univ. of Warsaw), ethnic studies, film studies, art history (Prof. Jerzy Kutnik, Maria Curie-Sklodowska Univ. of Lublin)...

8 Survey courses in the history of American literature and culture, as well as U.S. history, are offered to students from all countries of the European Union in all threeyear university B.A. programs, while the offer of graduate courses and seminars varies from university to university, depending on the interests of faculty.

9 Polish Americanists have been taking advantage of the benefits of the Fulbright Program which also serves as a channel for recruiting visiting professors of American Studies from the United States. 
INDEX

Keywords : Fulbright, American literature, History of Twentieth-Century American Literature 